\title{
SHAPING OF A MIDDLE SURFACE OF A DISHED HEAD OF A CIRCULAR CYLINDRICAL PRESSURE VESSEL
}

\author{
JERZY LEWIŃSKI \\ Poznan University of Technology, Institute of Applied Mechanics, Poznan, Poland \\ e-mail: jerzy.lewinski@put.poznan.pl \\ KRZYSZTOF MAGNUCKI \\ Poznan University of Technology, Institute of Applied Mechanics, Poznan, Poland \\ Institute of Rail Vehicles, Tabor, Poznan, Poland \\ krzysztof.magnucki@put.poznan.pl
}

The paper is devoted to a dished head of a pressure vessel subject to internal uniform pressure. A short survey of optimal design of the pressure vessel and its head is presented. The problem of shaping of the middle surface of the dished head with the use of trigonometric series is depicted. As a criterion of the shaping process, the continuity of curvatures of the surfaces in the joint of the circular cylindrical shell and the dished head is assumed. Results of the numerical calculation for optimal shapes of the head are presented in figures.

Key words: thin-walled pressure vessel, dished head, minimal stress concentration

\section{Introduction}

The standard torispherical, ellipsoidal or hemispherical head of a pressure vessel significantly disturbs the membrane stress pattern arising in its cylindrical part. The value of the meridional principal curvature of the middle head surface is non-zero while in the cylindrical it takes the zero level. In result, the curvature becomes discontinuous. The problem of dished heads of the vessels has been undertaken by many investigators. Middleton (1979) presented an optimal design problem of the torispherical pressure vessel head with the use of the penalty function procedure. Mansfield (1981) proposed the meridian shape in the form of an integral equation determining the optimal surface of revolution and compared the results with classical ellipsoidal and torispherical heads. Yushan and Wang (1996), Yushan et al. (1996) calculated stresses 
of ellipsoidal heads and noticed the stress concentration occurring there. Magnucki and Lewinski (2000) described the stress state arising in an untypical torispherical head composed of circular and polynomial parts. Magnucki et al. (2002) solved the problem of stress minimization of a vessel with an ellipsoidal head. Magnucki and Lewinski (2003) presented the optimal design of an ellipsoidal head with consideration of various thickness values of the shell. Malinowski and Magnucki (2005) minimized the stress concentration in sandwich ribbed flat baffle plates of a cylindrical tank. Krivoshapko (2007) presented a review of strength and buckling problems of generalized and ellipsoidal shells of pressure vessels. Liu et al. (2008) proposed a theoretical method using finite element analysis to calculate the plastic collapse loads of pressure vessels under internal pressure and compared the analytical methods according to three criteria stated in the ASME Boiler Pressure Vessel Code. Błachut sand Magnucki (2008) delivered a review of strength, static stability, and structural optimization of horizontal pressure vessels. Wittenbeck and Magnucki (2008) shaped the dished head meridian in the form of clothoidal and circular parts. Ventsel and Krauthammer (2001) delivered a monograph presenting the strength and stability problems of plates and shells with the edge effect of cylindrical shells.

The present paper is a continuation of the strength and optimization problems and deals with the shaping of the middle surface of dished heads with the use of trigonometric functions.

\section{Mathematical description of the middle surface of the dished head}

The shape of a head closing a cylindrical pressure vessel significantly affects the pattern of stress arising along its meridian. Since the stress depends, among others, on the meridian curvature, its radius of curvature should be continuous. Curvature of commonly used torispherical or ellipsoidal heads undergoes sudden variation in the contact point of the head and cylindrical parts of the meridian. This is due to the fact that the meridional curvature radius of the cylindrical part is equal to infinity, while the further course of the meridian belonging to the head is of a finite radius. In order to avoid such a situation, the head profile should begin from the infinite radius too. Such a shape of the head may be described by the following functions

$$
r(z)=a \widetilde{r}(\zeta)
$$

where 
$\widetilde{r}(\zeta) \quad-$ dimensionless radius, $\widetilde{r}(\zeta)=f_{0}(\zeta)=\alpha_{1} \cos (\pi \zeta)+\alpha_{2} \cos (2 \pi \zeta)+\alpha_{3} \cos (3 \pi \zeta)$

$\zeta \quad-$ dimensionless coordinate, $\zeta=z / b_{0}$

$b_{0} \quad-$ size (a linear quantity)

a - radius of the cylindrical shell.

The continuity conditions of the dimensionless radius for the joint of cylindrical shell and the dished head have the following form

$$
\widetilde{r}(0)=1 \quad \text { giving } \quad \alpha_{1}+\alpha_{2}+\alpha_{3}=1
$$

The other conditions that should be met by function (2.1) in order to ensure stepless variation of the radius are as follows

$$
\left.\frac{d \widetilde{r}}{d \zeta}\right|_{\zeta=0} \equiv 0 \quad \text { fulfilled by identity }
$$

The first of the above equations is satisfied by identity, while the other provides another condition for $\alpha_{1}, \alpha_{2}$, and $\alpha_{3}$

$$
\left.\frac{d^{2} r}{d \zeta^{2}}\right|_{\zeta=0}=0 \quad \text { giving } \quad \alpha_{1}+4 \alpha_{2}+9 \alpha_{3}=0
$$

This allows one to express the coefficients $\alpha_{2}$ and $\alpha_{3}$ in terms of $\alpha_{1}$

$$
\alpha_{2}=\frac{1}{5}\left(9-8 \alpha_{1}\right) \quad \alpha_{3}=\frac{1}{5}\left(3 \alpha_{1}-4\right)
$$

Thus, function (2.1) may smoothly match the cylindrical part of the vessel shape, but in order to provide a satisfactory shape of the head it must be completed by a circular part. Since the connection between the cosinusoidal and circular parts of the meridian should be smooth too, the circle should begin in the point at which the centre of curvature of cosinusoidal curve (2.1) reaches the axis of vessel symmetry.

The longitudinal-meridional curvature radius is

$$
R_{m}=\frac{\left[1+\left(\frac{d r}{d z}\right)^{2}\right]^{3 / 2}}{\left|\frac{d^{2} r}{d z^{2}}\right|}=a \frac{\left[1+\left(\frac{\pi}{\beta_{0}}\right)^{2} f_{1}^{2}(\zeta)\right]^{3 / 2}}{\left(\frac{\pi}{\beta_{0}}\right)^{2} f_{2}(\zeta)}
$$

and the circumferential-parallel curvature radius

$$
R_{e}=\frac{r(z)}{\cos \theta}=a f_{0}(\zeta) \sqrt{1+\left(\frac{\pi}{\beta_{0}}\right)^{2} f_{1}^{2}(\zeta)}
$$


where

$$
\begin{aligned}
& f_{1}(\zeta)=\alpha_{1} \sin (\pi \zeta)+2 \alpha_{2} \sin (2 \pi \zeta)+3 \alpha_{3} \sin (3 \pi \zeta) \\
& f_{2}(\zeta)=\alpha_{1} \cos (\pi \zeta)+4 \alpha_{2} \cos (2 \pi \zeta)+9 \alpha_{3} \cos (3 \pi \zeta) \\
& \beta_{0}=\frac{b_{0}}{a}
\end{aligned}
$$

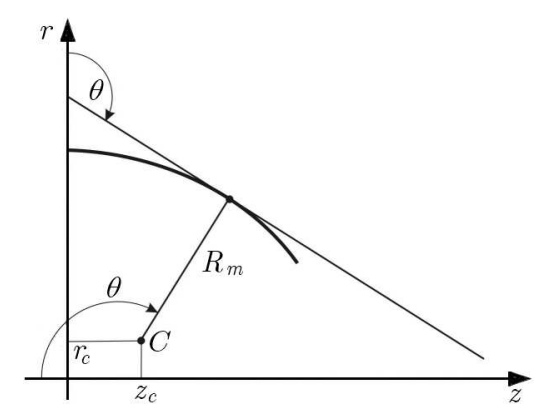

Fig. 1. Exemplary location of the centre of curvature for the point $M$ of the cosinusoidal curve

In any point of the considered curve its derivative equals the tangent of the angle $\theta\left((d r / d z)^{-1}=\tan \theta\right)$. Hence, according to Fig. 1, one might easily write the following expressions for the coordinates of the centre of curvature

$$
\begin{aligned}
& z_{c}=z-\frac{1+\left(\frac{d r}{d z}\right)^{2}}{\frac{d^{2} r}{d z^{2}}} \frac{d r}{d z}=a \beta_{0}\left\{\zeta-\frac{f_{1}(\zeta)}{\pi f_{2}(\zeta)}\left[1+\left(\frac{\pi}{\beta_{0}}\right)^{2} f_{1}^{2}(\zeta)\right]\right\} \\
& r_{c}=y+\frac{1+\left(\frac{d r}{d z}\right)^{2}}{\frac{d^{2} r}{d z^{2}}}=a\left\{\widetilde{r}(\zeta)-\frac{\beta_{0}^{2}}{\pi^{2} f_{2}(\zeta)}\left[1+\left(\frac{\pi}{\beta_{0}}\right)^{2} f_{1}^{2}(\zeta)\right]\right\}
\end{aligned}
$$

Taking into account relationship (2.5), cosinusoidal curve (2.1) is determined by two parameters: $\alpha_{1}$ and $b_{0}$. Therefore, once their values are assumed, one is able to find such a point $M$ at the cosinusoidal part of the curve from which the circular shape begins (Fig. 2).

In consequence, selection of pairs of $\alpha_{1}$ and $b_{0}$ parameters enables finding a family of head shapes of various values of the relative depth $\beta$ given by the formula

$$
\beta=\frac{b}{a}=\beta_{0} \zeta_{M}+\widetilde{R}_{m}\left(1+\cos \theta_{M}\right)
$$

where

$$
\zeta_{M}=\frac{z_{M}}{b_{0}} \quad \widetilde{R}_{m}=\frac{R_{m}}{a}
$$




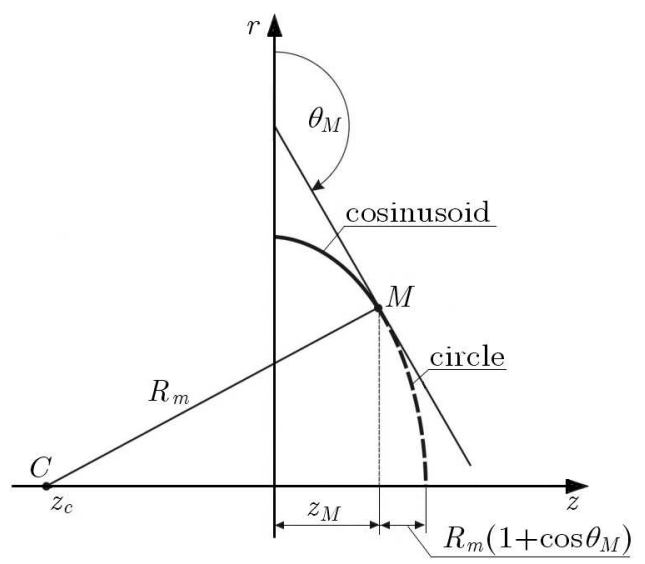

Fig. 2. The head shape composed of the cosinusoidal and circular parts connected at the point $M$

\section{Equivalent stress of the circular cylindrical vessel}

The longitudinal and circumferential stresses of the head are as follows

$$
\sigma_{m}=\frac{1}{2} R_{e} \frac{p_{0}}{t} \quad \sigma_{e}=\frac{1}{2} R_{e}\left(2-\frac{R_{e}}{R_{m}}\right) \frac{p_{0}}{t}
$$

where $p_{0}$ is the uniformly distributed pressure, $t$ - thickness of the head.

The equivalent stress (i.e. Huber-Mises stress) is

$$
\sigma_{e q}=\frac{1}{2} R_{e} \sqrt{3-3 \frac{R_{e}}{R_{m}}+\left(\frac{R_{e}}{R_{m}}\right)^{2}} \frac{p_{0}}{t} \quad \text { or } \quad \sigma_{e q}=\tilde{\sigma}_{e q} a \frac{p_{0}}{t}
$$

where the dimensionless equivalent stress is

$$
\widetilde{\sigma}_{e q}=\frac{1}{2} \widetilde{R}_{e} \sqrt{3-3 \frac{R_{e}}{R_{m}}+\left(\frac{R_{e}}{R_{m}}\right)^{2}} \quad \text { and } \quad \widetilde{R}_{e}=\frac{R_{e}}{a}
$$

Ventsel and Krauthammer (2001) described theory and applications of thin plates and shells, with consideration of the edge effect in thin-walled shells.

An exemplary variant of the head obtained for $\alpha_{1}=0.8, \alpha_{2}=0.52$, $\alpha_{3}=-0.32$ is shown in Fig. 3. Distribution of the dimensionless equivalent stress of this head is shown in Fig. 4.

The centre of curvature runs along its trajectory and intersects twice with the $x$-axis. This provides two possible solutions for the head. In the case of 


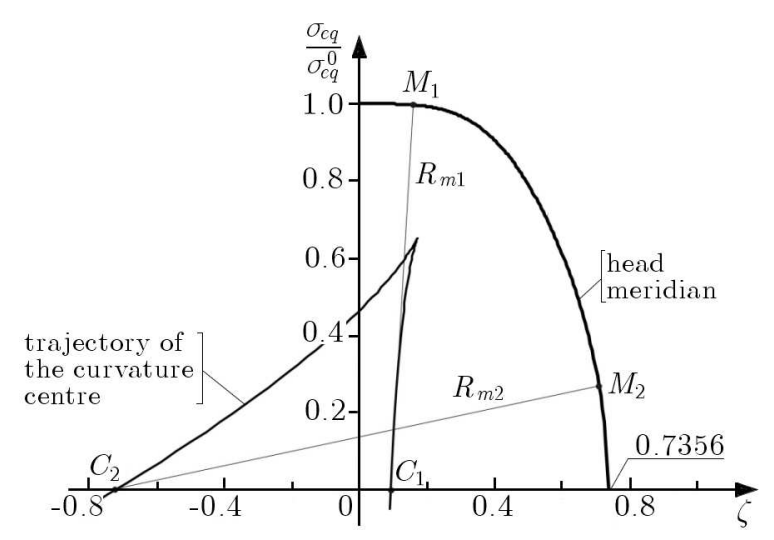

Fig. 3. Example of the head solution for $\alpha_{1}=0.8$ and $\beta_{0}=2$

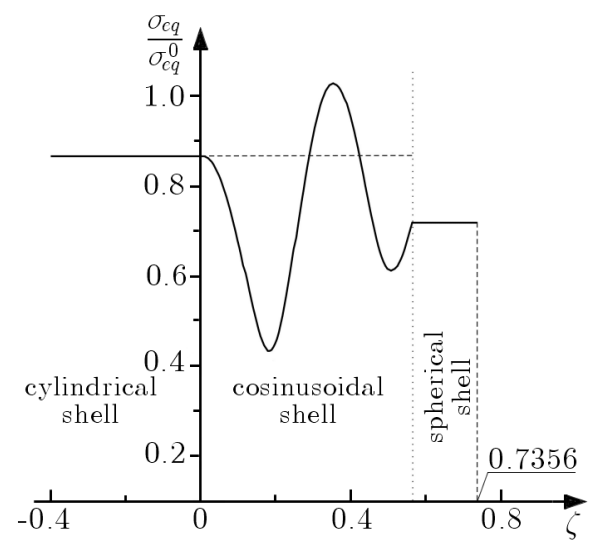

Fig. 4. Dimensionless equivalent stress for $\alpha_{1}=0.8, \beta_{0}=2$, and $\beta=0.7356$

connecting the circular part at the point $M_{1}$ making use of the centre $C_{1}$, the relative depth of the head would exceed unity, that is rather not recommended. An alternative solution obtained with the use of the points $M_{2}$ and $C_{2}$ gives the head meridian shown in the illustration, with the relative depth $\beta=0.7356$.

This is much better, however, the pattern of the dimensionless equivalent stress shown for the cosinusoidal part of the head is rather unfavourable as it exceeds the level of $\widetilde{\sigma}_{e q}^{0}=\sqrt{3} / 2$ occurring in the cylindrical part of the vessel.

The optimization problem of the head in terms of the variables $\alpha_{1}$ and $\beta_{0}$ is formulated as follows:

- optimization criterion

$$
\min _{\alpha_{1} \beta_{0}}\{\beta\}
$$


- constraints - the strength condition

$$
\widetilde{\sigma}_{e q, \max } \leqslant \frac{\sqrt{3}}{2}
$$

Therefore, the final solution to the problem should consist in finding a pair of $\alpha_{1}$ and $b_{0}$ parameters so adjusted as to obtain a possibly small $\beta$ value with the equivalent stress level kept below the value of $\widetilde{\sigma}_{e q}^{0}=\sqrt{3} / 2$.

Numerical analysis has shown that such a solution exists for $\alpha_{1}=1.2212$ and $\beta_{0}=1.6679$, which is depicted in Fig. 5 .

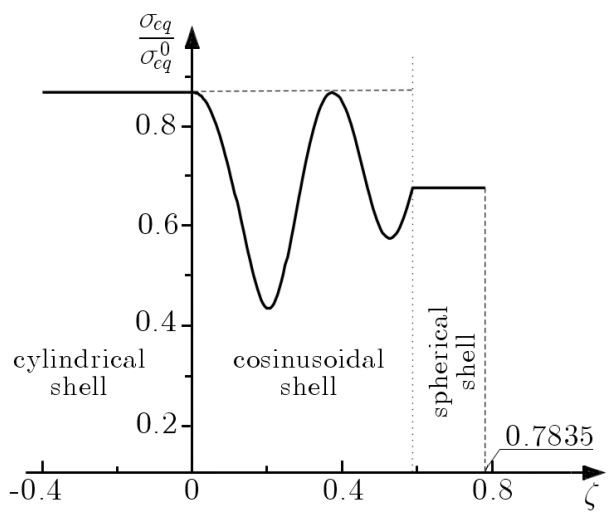

Fig. 5. Optimal pattern of the dimensionless equivalent stress for $\alpha_{1}=1.2212$,

$$
\beta_{0}=1.6679 \text {, and } \beta=0.7835
$$

The Gaussian curvature $1 /\left(R_{e} R_{m}\right)$ of the middle surface of the head varies significantly and, in consequence, disturbs the membrane state stress. This phenomenon may be alleviated by increasing the head depth.

The MES calculation carried out with the help of the ABAQUS system and shown in Fig. 6 confirmed the equivalent stress pattern obtained above for the central line. The computation was performed for an examplary vessel of the radius $1 \mathrm{~m}$ and shell thickness $10 \mathrm{~mm}$.

Figure 7 shows a graphical visualization of the equivalent stress at the inner surface of the vessel. It becomes evident that in this case the stress arising at the inner part of the head shell exceeds its level occurring in the cylindrical part.

Therefore, another attempt has been undertaken with a view to find a variant so adjusted as to keep the maximum stress at the level characteristic for the cylindrical part. This was possible by enlarging the relative depth of the head. Finally, the relative depth equal to $\beta=0.8384$ gave a satisfactory result depicted in Figs. 8 and 9. 


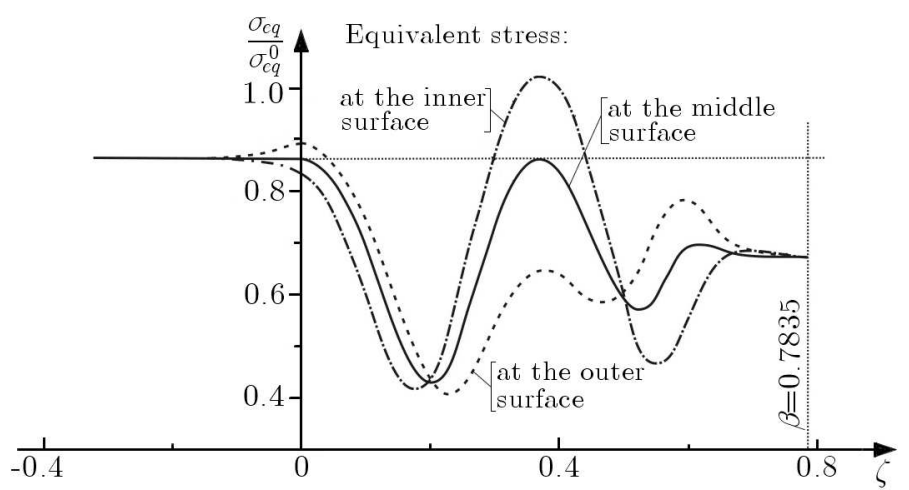

Fig. 6. Equivalent stresses at the middle, inner and outer surfaces of the head

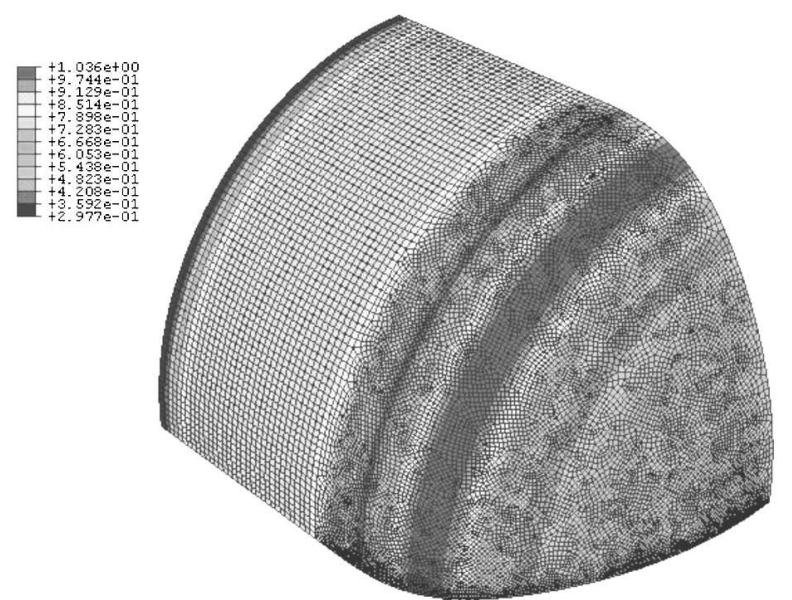

Fig. 7. Visualization of the equivalent stress at the inner surface

\section{Conclusions}

The presented numerical study of the stress state of a cylindrical pressure vessel with convex cosinusoidal-spherical heads enables drawing the following conclusions:

- Fulfillment of the condition of continuous curvature in the joint between the head and the cylindrical shell is not sufficient to avoid stress concentration in this place.

- Further increase in the head depth reduces the value of the concentrated stress.

- As a result of shaping the head according to the boundary effect theory, the relative depth $\beta=0.784$ has been obtained for which the stress 


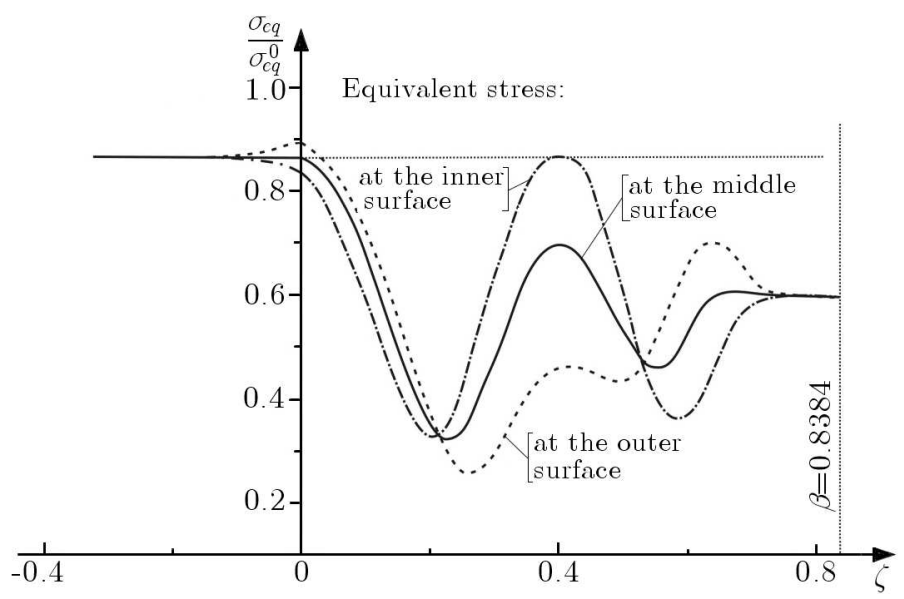

Fig. 8. Equivalent stresses at the middle, inner and outer surfaces of the head for the variant with enlarged relative depth of the head

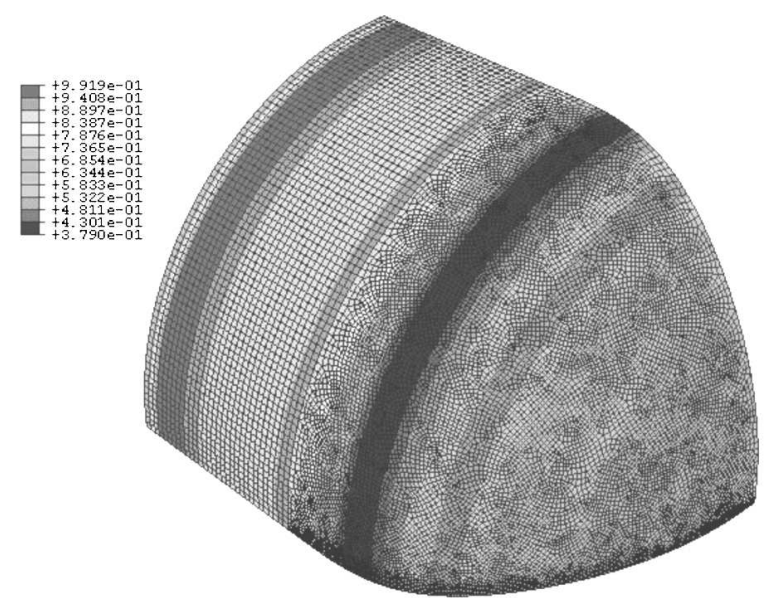

Fig. 9. Visualization of the equivalent stress at the inner surface for the variant with enlarged relative depth of the head

concentration should disappear. Nevertheless, a numerical test with the help of FEM has shown the opposite (Fig. 6).

- Increase in the relative depth up to $\beta=0.838$ eliminates the stress concentration (Fig. 8).

It should be noticed that the relative depth of standard ellipsoidal heads amounts to the value of $\beta=0.5$ at which a remarkable stress concentration occurs. 


\section{References}

1. BŁachut J., Magnucki K., 2008, Strength, stability, and optimization of pressure vessels: Review of selected problems, Applied Mechanics Reviews, 61, $6,1-33$

2. Krivoshapko S.N., 2007, Research on general and axisymmetric ellipsoidal shells used as domes, pressure vessels, and tanks, Applied Mechanics Reviews, 60, 6, 336-355

3. Liu P.-F., Zheng J.-Y., Ma L., Miao C.-J., Wu L.-L., 2008, Calculations of plastic collapse load of pressure vessel using FEA, Journal of Zhejiang University Science A, 9, 7, 900-906

4. Magnucki K., Lewiński J., 2000, Fully stressed head of a pressure vessel, Thin-Walled Structures, 38, 167-178

5. Magnucki K., Szyc W., Lewiński J., 2002, Minimization of stress concentration factor in cylindrical pressure vessels with ellipsoidal heads, Int. J. Press Vessel Piping, 79, 841-846

6. Magnucki K., Lewiński J., 2003, Optimal design of an ellipsoidal head of a pressure cylindrical vessel, Proc. Appl. Math. Mech., 3, 517-518

7. Malinowski M., Magnucki K., 2005, Optimal design of sandwich ribbed flat baffle plates of a circular cylindrical tank, Int. J. Press Vessel Piping, 82, $227-233$

8. Mansfield E.H., 1981, An optimum surface of revolution for pressurized shells, Int. Journal of Mechanical Science, 23, 57-62

9. Middleton J., 1979, Optimal design of torispherical pressure vessel end closures, Engineering Optimization, 4, 129-138

10. Wittembeck L., Magnucki K., 2008, Strength shaping of dished heads of pressure cylindrical vessels, Proceedings of the Ninth Int. Conference on Computational Structures Technology, B.H.V. Topping and M. Papadrakakis (Edit.), Civil-Comp Press, Stirlingshire, Scotland (Paper 138, CD)

11. Yushan Z., WAng Z.R., 1996, Stress analysis of two-arc approximate ellipsoidal pressure vessel heads and parameter optimization, Int. J. Press Vessel Piping, 67, 199-202

12. Yushan Z., Wang Z.R., Wei C., 1996, Stress analysis of approximately ellipsoidal cold-spun tri-arc tank head and parameter optimization, Int. J. Press Vessel Piping, 68, 237-242

13. Ventsel E., Krauthammer T., 2001, Thin plates and shells. Theory, analysis and applications, Marcel Dekker, Inc, New York, Basel 


\section{Kształtowanie środkowej powierzchni wypukłego dna walcowego zbiornika ciśnieniowego}

\section{Streszczenie}

Praca dotyczy dna wypukłego walcowego zbiornika ciśnieniowego obciążonego równomiernym ciśnieniem wewnętrznym. Zamieszczono krótki przegląd problemu optymalnego projektowania zbiornika i jego dna. Przedstawiono problem kształtowania środkowej powierzchni wypukłego dna z zastosowaniem szeregu trygonometrycznego. Warunek ograniczajaccy kształt południka dna dotyczy ciągłości krzywizn w miejscu połączenia z powłoką walcową. Poszukiwano rozwiązania optymalnego, w którym głębokość dna jest minimalna przy ograniczeniu warunkiem wytrzymałości. Wyniki numerycznych obliczeń optymalnych kształtów dna przedstawiono na rysunkach.

Manuscript received May 6, 2009; accepted for print July 9, 2009 